\title{
The Impact of Letter of Intent as Gatekeeping Encounters on Saudi Students Graduate Applications
}

\author{
Maha Abdulwahed Alzahrani ${ }^{1, *}$ \\ ${ }^{1}$ Ontario Institute for Studies in Education, University of Toronto, Toronto, ON, Canada \\ *Correspondence: Ontario Institute for Studies in Education, University of Toronto, Toronto, ON, Canada. E-mail: \\ maha.alzahrani@mail.utoronto.ca
}

Received: April 16, 2018

Accepted: May 24, 2018 Online Published: June 12, 2018

doi:10.5430/ijelt.v5n2p12

URL: https://doi.org/10.5430/ijelt.v5n2p12

\begin{abstract}
This qualitative study examines the challenges faced by Saudi students in the process of applying to graduate programs while studying in an anglophone country. Through the lens of gatekeeping scholarship, this study sought to shed light on the role of letter of intent on predicting the success of Saudi students with their graduate programs applications. Writing a letter of intent in one of the main factors influencing students' applications. Data collected was mainly through semi-structured interviews and analysis of the students' letters of intent. In conclusion, the letters of intent were found to be one of the defining factors in successful graduate applications.
\end{abstract}

Keywords: admission, letter of intent, Saudi students, graduate application, gatekeeping encounters

\section{Background}

In light of the high numbers of Saudi students who arrive in Canada with aspirations of completing graduate school, it is important to consider how, or even whether, their English as a second language learning adequately prepares them for success in attaining their goal. I am one of these students and based on a second language theory course I took which enabled me to make sense of my reflections, I decided to draw on a wealth of research encompassing gatekeeping as a lens through which to investigate my topic, namely the perceptions and experiences of international students learning about writing their letter of intent to gain admission into their desired graduate program.

\section{Gatekeeping in University Admission}

The concept of gatekeeping refers to a metaphor associated with the procedure of checking progression over stages through critical points of entry (Homrich, 2009). This term also refers to an individual who makes evaluation decisions and allows entry via specific points when certain competencies have been successfully proven. (Homrich, 2009; Brear, Dorrian and Luscri, 2008).

A similar definition was introduced by Dora (2003), who described gatekeeping as a method of evaluating and screening students' performance where academic staff and field professors are responsible for playing the role of gatekeepers. According to Husu (2011) gatekeeping serves two roles. The first is to enable and promote ideas, people and policies as well as provide opportunities. The second role is to help to control, exclude and block people and ideas not in keeping with the status quo of the system. Gatekeeping manifests in every social system (Husu, 2011). For example, in universities gatekeeping impacts the creation of academic appointments, agenda setting, establishment of policy, resource allocation to different departments, who gets recruited and promoted within the departments, who gets funding, and other recognition such as awards and prizes. In academic journals the phenomenon affects which researchers' ideas get published versus those who are sidelined.

Furthermore, Koerin \& Miller (1995) stated that gatekeeping in the educational process refers to a monitoring system applied in order to hamper the entry of students who do not possess the required skills and knowledge in education programs. In other words, the admissions process plays a gatekeeping function to increase the likelihood that admitted students will perform to acceptable standards and successfully obtain their degrees. Other examples include 
completing required courses, achieving specific minimum grades, and successfully defending a thesis or dissertation.

In the graduate application process, gatekeeping factors include grade reports from prior institutions, the student's personal statement and $\mathrm{CV}$ outlining prior work experience. International students whose first language is not English must also demonstrate language proficiency, most often through the IELTS which consists of written, reading, oral and listening sections, all of which serve gatekeeping functions. This study did not include grade reports along with the other gatekeeping factors because the grade reports are objective factors while the letter of intent and $\mathrm{CV}$ are subjective.

\section{The Letter of Intent}

The letter of intent is a key albeit subjective component of the graduate application. It is an opportunity to introduce the applicant's personal and professional development, research areas and work experience, academic background and career goals to the admissions committee (Keith-Spiegel \& Wiederman, 2000; Brown, 2004; Early \& DeCosta-Smith, 2012). On a simplistic level, it is considered appropriate when the information is written using correct grammar, spelling and presented in a clear and brief style (Smith et al 2005). On a deeper level, it has the potential of serving as a gate opener due to its impact if it is written in such a way as to "illustrate [the applicant's] character in action" and relay academic and practical experiences in a reflexive manner, demonstrating how these experiences have affected their professional development (Brown, 2004), in other words, if the personal statement makes a strong case for how the candidate would be an ideal fit for the program.

\section{The Aim of the Study}

This study aims at exploring factors influencing the application process of Saudi students studying in Canada. Letter of intent is one of the main factors that I have explicitly discussed in this paper.

Research Question:

1- Does the verbal discourse the students express in their interviews correlate with information contained in their supporting documents (letters of intent), and, ultimately, did these supporting documents help to bring about the desired outcome?

\section{Data and Method}

To collect the data for this study, I used three types of participant interviews including one-on-one live interviews, one-on-one Skype interviews and one focus group. Letter of intent was also used as a part of the data.

\subsection{Participants}

Fourteen participants were interviewed, one man and 13 women. Both genders were invited to participate in the study. I was seeking a more equitable distribution of male and female participants, but only two men showed interest and only one followed through with an interview. Participants were solely composed of individuals educated in Saudi Arabia prior to their move to Canada. The other requirement from the participants was their interest and willingness to be a part of my study as well as providing me with their letter of intent was essential to completing the data. Participants were between the ages of 22 and 30 since one of the conditions for the applicant to be eligible for scholarship is that he or she must not be over 27 years old at the time of application.

\subsection{Participant Interviews}

This study primarily relied on semi-structured interviews of current graduate students. Additional students who had applied to post-secondary education but had their applications rejected were also queried. These participants provided information relevant to the aforementioned research questions. In addition, the respondents were asked about their scores on standardized language tests, the number of years they spent studying English, as well as their education history and high school grades. To further examine their experiences, past and current feelings about their competency were also queried and discussed. Data collection and collation proceeded over the course of three months, which provided ample time to find participants, gather interview information, and collate and analyze the data.

Interviews proceeded smoothly with everyone; I interviewed the participants separately except for three (Leena, Deema and Rama) whom I interviewed as a focus group. I conducted eight interviews over Skype with students 
located outside of the GTA in cities such as Thunder Bay, Saint John's and Waterloo, who were not planning to travel to Toronto in the near future.

Participants were asked to respond to a series of semi-structured interview questions. Semi-structured interviews are designed and scheduled in advance and usually take place at a designated time and location away from everyday events. These interviews are usually centered on a set of predetermined open-ended questions, with other questions deriving from the dialogue between interviewer and interviewee (DiCicco-Bloom \& Crabtree, 2006). I decided to use semi-structured interviews in my research simply because this approach could provide a very flexible technique for a small-scale study (Drever, 1995)

\subsection{Analysis}

I asked participants to provide me with their documents during the interview or via email. Analyzing these documents took place by focusing on two attributes, first, their content, and second, that they were written using the grammatical and stylistic conventions expected for North American style professional documents. Documents of those who have obtained acceptance versus others who have not, were examined. I adapted two templates for both documents which I used to analyze the letters of intent. Each aspect of the document was given a code; for the letters of intent, the codes are alphanumeric. See table 1.

Table 1. Template of an Ideal Letter of Intent Subdivided into Coded Categories and Inspired by Furka (2008) Smith et al. (2005) University of Toronto (2015) and Purdue University (2015)

\begin{tabular}{|c|c|c|c|c|}
\hline $\begin{array}{l}\text { Move } \\
\text { Code }\end{array}$ & $\begin{array}{l}\text { Move type } \\
\text { category }\end{array}$ & Example & & Description \\
\hline \multirow[b]{2}{*}{ A } & \multirow[b]{2}{*}{$\begin{array}{l}\text { Introduce } \\
\text { candidature }\end{array}$} & \multirow[b]{2}{*}{$\begin{array}{l}\text { Candidate introduces } \\
\text { self and states objective }\end{array}$} & \multirow{2}{*}{$\begin{array}{c}\text { Ineffective } \\
\text { Career objective } \\
\text { not clearly stated }\end{array}$} & \multirow{4}{*}{$\begin{array}{c}\text { Effective } \\
\text { Introduces self and states objective clearly } \\
\text { Applicant describes past academic activities } \\
\text { such as summer research jobs, } \\
\text { independent-study projects, with an emphasis } \\
\text { on what was learned from these activities, and } \\
\text { indicating how studies in graduate program } \\
\text { will extend that learning. } \\
\text { Candidate uses this prompt to highlight a } \\
\text { personal strength e.g. that they are a proven } \\
\text { achiever, or that they can overcome } \\
\text { challenges. }\end{array}$} \\
\hline & & & & \\
\hline B & & Academic history & \multirow{3}{*}{$\begin{array}{l}\text { Factual description } \\
\text { of achievements } \\
\text { without a strong } \\
\text { interpretive } \\
\text { element. }\end{array}$} & \\
\hline & $\begin{array}{l}\text { Establish } \\
\text { credentials }\end{array}$ & $\begin{array}{l}\text { Personal attributes that } \\
\text { would affect training }\end{array}$ & & \\
\hline $\mathrm{C}$ & $\begin{array}{l}\text { Essential } \\
\text { Detailing of } \\
\text { Candidature }\end{array}$ & $\begin{array}{l}\text { Connection to } \\
\text { program/area }\end{array}$ & & $\begin{array}{l}\text { Discusses interests in terms of key issues and } \\
\text { theories in discipline. Claims made are } \\
\text { backed up with facts. Reference made to facts } \\
\text { in other parts of the application ("as my } \\
\text { academic record shows"), offering enough } \\
\text { examples. Language is concrete, specific } \\
\text { with nouns and adjectives which describe } \\
\text { desirable qualities }\end{array}$ \\
\hline \multirow{2}{*}{$\mathrm{D}$} & \multirow{2}{*}{$\begin{array}{l}\text { Offer value } \\
\text { of } \\
\text { candidacy } \\
\text { to } \\
\text { university } \\
\text { department }\end{array}$} & $\begin{array}{l}\text { State expectations } \\
\text { student has of program } \\
\text { and future plans }\end{array}$ & $\begin{array}{l}\text { Outlining the topic } \\
\text { candidate wishes to } \\
\text { work on without } \\
\text { offering value of } \\
\text { candidacy to the } \\
\text { department }\end{array}$ & $\begin{array}{l}\text { Answers the central question of why } \\
\text { candidate is an ideal match for the program, } \\
\text { has something special to contribute to the } \\
\text { profession. Predict contributions to the field. }\end{array}$ \\
\hline & & $\begin{array}{l}\text { Personal information } \\
\text { such as hobbies and } \\
\text { other details not } \\
\text { necessarily related to } \\
\text { the major }\end{array}$ & $\begin{array}{l}\text { Self-centered } \\
\text { description of } \\
\text { personality i.e. } \\
\text { mere "showing } \\
\quad \text { off". }\end{array}$ & $\begin{array}{l}\text { Use to demonstrate the candidate is clear } \\
\text { minded, sensible and mature, able to handle } \\
\text { the demands of graduate school. Mention } \\
\text { attributes not placed elsewhere in the } \\
\text { application if relevant to candidacy. }\end{array}$ \\
\hline
\end{tabular}




\section{Results}

\subsection{Letter of intent}

One of the requirements for graduate program entry is to prepare a letter of intent. The participants provided me with the letters of intent submitted when they applied to their graduate programs. Most of my interviewees disclosed that they did not write their letters by themselves but sought outside help to understand what was required in terms of content and structure. They consulted people who had experience with this genre of writing. According to the 14 participants in my study:

-11 of them admitted that they did not write their letter; instead, they had someone else (a friend, husband or editor) write the whole statement.

Table 2. Summary of Analysis of Letters of Intent by Move Type

\begin{tabular}{|c|c|c|c|c|c|c|c|c|c|c|c|c|c|}
\hline $\begin{array}{l}\text { Document and } \\
\text { move code }\end{array}$ & Partici & ipant & & & & & & & & & & & \\
\hline & Afnan & Ahmad & Rawa & Shahad & Deema & Kadi Leena & Muna & Nada & Basmah & Noura & Rama & Reem & Sara \\
\hline LOI & & & & & & & & & & & & & \\
\hline A & Yes & N/A & Yes & Yes & Yes & N/A N/A & Yes & Yes & N/A & Yes & Yes & Yes & Yes \\
\hline B & Yes & $\mathrm{N} / \mathrm{A}$ & Yes & Yes & Yes & N/A N/A & No & Yes & $\mathrm{N} / \mathrm{A}$ & Yes & Yes & Yes & Yes \\
\hline $\mathrm{C}$ & Yes & N/A & Yes & Yes & Yes & N/A N/A & No & Yes & N/A & Yes & Yes & Yes & Yes \\
\hline $\mathrm{D}$ & Yes & N/A & Yes & Yes & Yes & N/A N/A & Yes & Yes & N/A & Yes & Yes & Yes & No \\
\hline Overall Strength & & & & & & & & & & & & & \\
\hline $\begin{array}{l}\text { "S" Or } \\
\text { Weakness "W" } \\
\text { of Loi }\end{array}$ & $\mathrm{S}$ & N/A & S & S & $\mathrm{S}$ & N/A N/A & W & $\mathrm{S}$ & N/A & $\mathrm{S}$ & $\mathrm{S}$ & $\mathrm{S}$ & $\mathrm{S}$ \\
\hline
\end{tabular}

\section{Key}

Yes $=$ Effective answer

$\mathrm{CNF}=$ Answer effective but Native speaker conventions not followed $\mathrm{No}=$ ineffective answer

$\mathrm{N} / \mathrm{A}=$ not completed

The reason unanimously given for seeking outside help was the participants' concerns about their level of proficiency in English. Since they had to write the letter early in their preparatory ESL period, they felt they did not possess the required level of writing. They wanted the letter to be perfect as they knew it would play a crucial role in their applications. In addition to citing the mechanics of English as being a stumbling block, the participants also explained they did not have experience with writing that involved self-reflection on the part of the applicant. Hence, they enlisted the help of Saudi graduate students who had written letters of intent the previous year. Deema, Nada, Sara, Reem and Muna all said they had easy access to acquaintances and friends ahead of them in the scholarship program who were more than happy to lend a hand. Leena was even more fortunate; her husband Ahmed, the sole participant with native speaker ability, wrote her letter of intent. He did ask her several questions, but with an in-depth knowledge of her personality, penned a comprehensive exposition accentuating her strengths.

Maha: Who did help you in writing the letter?

Deema: I asked my friend first if she knew someone to help. She contacted me to Saudi student who helps in writing.

Maha: Did he wrote everything?

Deema: Yes, he asked questions about my degrees and experience then wrote the draft.

Maha: You did not try to write a first draft by yourself? Deema: No. 
Maha: Can I ask why?

Deema: I can't at that time, my writing was not very good.

Others who were prepared to study in Canada and had the ability to write their letters of intent by themselves at least wrote a first draft and only later sought editing. Rama had not procured an acceptance at the time of writing although she had become fluent in English, having completed a four-year nursing degree in English and earned an IELTS score of 6.5 out of 9. She wrote the letter independently after consulting with her teachers in schools in addition to going online to investigate more about her program. She had the courage to draft it. Then she made use of the skills of a native speaking English editor plus a non-native speaker to double-check her writing.

She recalled that "it was a shock when I [learned] that there is something called [a] letter of intent that I have to submit with my application."

Ahmad was proficient enough in English that he wrote his letter by himself. He consulted his father and researched online; nonetheless, he did not employ an editing service. Shahad, on the other hand, noted, "I tried to write it and then had a non-native speaker [go] over it." She also insisted on the importance of reading sample letters because it helped her to form a clear idea of the requirements.

Regarding the letters themselves, first, I started to read each letter individually and formed my first impressions on them. Most of them were well written with minor errors consistent with those that the non-native speakers who had composed them would make. Then I reread the letters to examine whether they contained the four components expected by an admissions committee: namely, an introduction of the candidature, the establishment of credentials, essential detailing of candidature and an offer of value of the candidacy to the department (see table 2). I applied one of the four codes (yes, no, CNF or N/A) to each component of the letter. After examining the letters in depth, I would describe them as successful or strong "s", versus unsuccessful or weak "w". A letter that contained over $50 \%$ of "Yes" codes would be considered successful, while one which contained $50 \%$ or more "no", "CNF" and "N/A" codes would be considered unsuccessful. All but one letters of intent were strong. This suggests that it is possible letters of intent may play a reduced role in decisions relating to admissions. It is possible that some letters may never be reviewed in situations where a student's level of English proficiency scores are too weak. English proficiency level thus acts as a gatekeeper for continuing on in the admissions process. Importantly, this finding also highlights the critical importance of conducting phone or in-person interviews with potential candidates. The interview provides valuable information that cannot be edited or completed by anyone other than the student themselves. Thus, it may be prudent for admissions committees to place additional weight on these interviews along with a somewhat reduced weight on letters.

The only weak letter I received was submitted by a science major. While her objective was clearly stated, other factors had a negative effect on her letter, for example, the description of her achievements, which simply comprised a list of undeveloped points. She also did not demonstrate her topic and show her ability to offer value to the program. Muna had been accepted through bridging courses. In contrast to Muna's positive results were the negative results of two candidates who nevertheless had strong documents.

One was a letter composed by the participant herself, and then edited by a native speaker. As of Fall 2015, the applicant had not yet attained an offer of graduate admission. This was Rama's four page letter which contained effective (as defined in table 2) versions of all four moves; it contained well-developed details about her background in nursing, reflexive in describing what being a nurse meant to her, unequivocal on the value she would bring to the graduate program and straightforward about her mature, cooperative and capable personality. In my opinion, the paper demonstrated excellence for a number of reasons. First, because Rama wrote it herself in the first place she was able to expound in detail about her own experience and of her eagerness to pursue that major. Having a letter written by an outside individual may yield improved grammar and vocabulary. However, this can come at the expense of creating a touching and personal letter that truly encapsulates a student's life history and goals

Another letter written by a successful applicant started with an introduction about the major "Physics," in which the prospect stated her previous experience in writing a research paper in her major with specific details including feedback and impressions from her professor. After that, she talked about her spare time activities. The strongest point in the letter is when she introduced the scholarship program and its goal. The last two paragraphs contained experience in Canada and future career goals. Yet, the low IELTS score, barred her from entry and she resorted to lobbying the professor.

One interesting case involves a student applying to a business program. This individual applied to a single school and was accepted. Given that students often must apply to 5 or perhaps 10 schools to increase their likelihood of 
acceptance, it becomes important to review their letter of intent in more detail for possible evidence that might explain her acceptance. Several factors emerged in her letter: formatting, organization of the paragraphs and content. In the first paragraph, she introduced the content of the letter and by so doing so, gave the reader a clear idea of what to expect in subsequent paragraphs. She then proceeded to discuss at length her academic background, major, paid work experience, volunteering and personal qualities. The last two paragraphs included statements of how the applicant had compared different graduate programs in Canada and decided to pursue her study in her chosen university to assure the gatekeepers she was serious about attending there and had thus thoroughly researched the program and its Canadian alternatives. Thus, it appears that this student's likelihood of acceptance was improved by ensuring that critical letter components were conveyed in a concise and accurate manner. This speaks to the importance of presenting a strong letter that can be reviewed once a student's moves past the common gatekeeper of English proficiency scores.

\section{Discussion}

\subsection{The Written Document (Letter of intent)}

In this section, I will discuss the findings regarding the letter of intent as indicators of applicants' ability to present themselves in the best light in written form to the admissions committee gatekeepers. The letters' role as a gatekeeping factor will be discussed.

First, using the strategy of hiring someone to write and edit the document seemed helpful for the participants in terms of decreasing the tension and the stress they had. Ahmad was confident enough to write and submit a letter that he had written himself, because of his high IELTS and TOEFL scores as well as his overall competency in English, all of which he noted in our discourse in the first phase of data collection. Others might not jeopardize their chances for acceptance with low quality writing in their letters of intent, given that the schemata and thought patterns of languages may differ (Kaplan, 1987; Furka, 2008) particularly in linguistically distant languages such as Arabic and English, and the competitive nature of university admissions landscape. As noted above, this finding also shows that admissions committees are only gaining a narrow understanding of a candidate's abilities when they rely too heavily on letters. Rather, the use of in-person or perhaps phone interviews is critical for ensuring requisite English communication skills. Given the necessity of these abilities to success in graduate school, admissions committees should place greater weight on this aspect of a potential student's application profile. Based on the answers given from two of the participants who did write their letters by themselves, I believe that there is a positive correlation between how competent the applicants are in their writing skills and how much risk they are willing to take when it comes to writing the letter (or at least the first draft of it) instead of handing the work to a professional editor or to peers.

As discussed in the findings, participants sought help when writing their documents due to two given reasons, namely the level of English and the unfamiliarity with how to write this genre of text. Early and DeCosta (2012) pointed out that students look for assistance from their English instructors or parents. In the case of the participants in this study, many asked their ESL teachers and two said they asked their fathers. This type of writing is hard for students who are still in the process of learning English and for those with parents unable to provide feedback (Early \& DeCosta, 2012), a point that was reflected in all my participants' answers except Ahmed, the lone C2. They were in their first year of learning English in Canada and did not feel confident in articulating their past achievements and future goals in English. That feeling of incompetence was a common theme in their answers, consequently, these participants fit under the unprepared learners. The time of writing the documents required from the participants was also a main constraint, as I noticed during the interviews that the participants wanted to have their documents ready even before finishing their preparatory English programs. This kind of writing required students to be reflective but the major issue with Saudi students was their prior language learning, mainly the passive traditional way where they were not prepared to write or reflect. Even before coming to Canada, no workshops or sessions were given to the participants to introduce these two important elements of the graduate applications. Randazzo (2012) underlined the process of reflexivity in the resume and letters and that the assistance of a mentor is required for students who are unfamiliar with this technique. Universities in North America, The United Kingdom, Australia and many countries around the globe look for specific criteria when assessing applications to graduate pro- grams (Early \& DeCosta, 2012). One of these criteria, as stated by the National Association for College Admission Counseling (NACAC, 2008), is the applicant's ability to pay for the programs. Saudi students have an advantage when applying to graduate schools, for all of them are fully funded by the government. It is important to indicate this factor on their letters in order to sell themselves to the admissions committee. That was reflected in letters provided by the participants. The 
strongest point I found in the letters is how the applicants expressed their gratitude about being granted a scholarship and linked these feelings to a high level of ambition and desire to pursue higher education in Canada.

\section{Limitations}

The results gleaned from this research are primarily relevant to other Saudi students currently studying and using English in Canada. Therefore, without further investigation and examination, it would be impossible, and therefore unrealistic, to draw conclusions and reliable comparisons against speakers of other languages such as Mandarin or Spanish. Additionally, these results could be used to inform admissions committees of the potential that the applicant may not have written letters. As a result, this could lead to changes in decision making regarding the importance of letters compared to other aspects of a student's application profile (e.g., interviews, undergraduate academic performance, etc.).

\section{Conclusion}

To conclude this study, after examining the letters of intent and their role on student's application, it is important to note that other factors such as English language proficiency, IETLS test score may play a more significant role on the applications. The participants were not able to write their letters, but they were successfully able to find ways and interact with professional writers and editors to articulate an adequate letters.

\section{References}

Brear, P., Dorrian, J., \& Luscri, G. (2008). Preparing our future counseling professionals: Gatekeeping and the implications for research. Counselling and Psychotherapy Research, 8(2), 93-101. https://doi.org/10.1080/14733140802007855

Brown, R., M. (2004). Self-composed rhetoric in psychology personal statements. Written Communication, 21(3), 242-260.

DiCicco-Bloom, B., \& Crabtree, B. F. (2006). The Qualitative Research Interview. Med Educ, 40, 314-321. https://doi.org/10.1111/j.1365-2929.2006.02418.x

Dora M.Y., T. (2003). Gatekeeping in Bachelor of Social Work field education. Women in Welfare Education Collective, 6, 51-63.

Drever, E. (1995). Using semi-structured interviews in small-scale research: A teacher's guide. Edinburgh: Scottish Council for Research in Education.

Early, J. S., \& DeCosta Smith, M. (2012). Real world writing for secondary students: teaching the college admission essay and other gate-openers for higher education: Teachers College Press and National Writing Project. Retrieved from http://www.nwp.org/cs/public/download/nwp_file/17018/earlydecosta_chap4.pdf?x-r=pcfile_d

Furka, I. (2008). The curriculum vitae and the motivational letter: a rhetorical and cultural analysis. WoPaLP, 7 , 18-73.

Husu, L. (2011). Gatekeeping of excellence and gender equality. Retrieved on 22 Nov. 2015 from www.genderscience.org

Kaplan, R. B. (1987). Cultural thought patterns revisited. In R. B. Kaplan, \& U. Connor (Eds.), Writing across languages: analysis of L2 text (pp. 9-21.). Reading, MA: Addison-Wesley.

Keith-Spiegel, P., \& Wiederman, M. W. (2000). The complete guide to graduate school admission: psychology, counseling, and related professions. Retrieved on 23 Nov. 2015 from http://www.amazon.com/exec/obidos/ASIN/0805831215/sociapsychn0f- 20 (2nd ed.). Mahwah, NJ: Lawrence Erlbaum Associates.

Koerin, B., \& Miller, L.S. (1995). Gatekeeping policies: Terminating students for non-academic reasons. Journal of Social Work Education, 31(2), 247-260. https://doi.org/10.1080/10437797.1995.10672261

National Association for College Admissions Counseling. (2008). Report of the commission on the use of standardized tests in undergraduate admissions. Arlington, VA: Author.

Purdue online writing lab. (2015). Writing the personal statement. Retrieved on 27 Nov. 2015 from 
https://owl.english.purdue.edu/owl/resource/642/01/

Randazzo, C. (2012). Positioning Résumés and Cover Letters as Reflective Reflexive Process. Business Communication Quarterly, 75(4), 377-391. https://doi.org/10.1177/1080569912459267

Smith, E. A., Weyhing, B., Mody, Y., \& Smith, W. L. (2005). A critical analysis of personal statements submitted by radiology residency applicants. AcadRadiol, 12, 1024-1028. https://doi.org/10.1016/j.acra.2005.04.006

University of Toronto. (2015). Application Letters and Résumés. Retrieved on 23 Nov. 2015 from $\mathrm{http} / / / \mathrm{www} . w r i t i n g . u t o r o n t o . c a / a d v i c e /$ specific-types-of-writing/application-letters

\section{Appendix A: interview questions}

Letter of intent

1. How did you find the process of writing the letter of intent?

2. Did you write your documents by yourself?

If yes,

3. What resources did u use?

4. Did you go online and read about your program? Which websites (academic and/or professional) did you consult?

5. Did u get someone to edit after you wrote the initial draft(s)?

If no,

1. Why did you get someone else to write the letter for you?

2. Who wrote it for you?

3. What information did you provide them- examples, your major, school, personal interests, professional goals?

4. What did the person writing the letter ask you for?

5. How did u communicate with the letter writer/editor? By Skype, phone, email, in person? 